\title{
Surge in Down syndrome prenatal testing anticipated
}

$\mathrm{W}$

hen a genetic test provides accurate information earlier, cheaper and safer than its predecessors, it's likely to become a popular item. This appears to be the case with a new noninvasive prenatal test for fetal chromosomal abnormalities. Some physicians are concerned, however, that the medical community is not prepared to educate and counsel a potentially huge number of pregnant women facing difficult family planning decisions.

The test, MaterniT21 PLUS, can detect Down syndrome, as well as trisomy 13 and 18 . The most common existing tests for these conditions, such as amniocentesis and chorionic villus sampling (CVS), involve the insertion of a needle through the abdomen to acquire cells to be tested for chromosomal abnormalities. These procedures carry some risk, including a small possibility of miscarriage. But MaterniT21 PLUS - made by Sequenom, a company based in San Diego, California requires only a maternal blood sample.

"This will be the first noninvasive blood test on the market recommended to all pregnant women," says Dr. Brian Skotko, a medical geneticist in the Down syndrome program at Children's Hospital Boston in Massachusetts. "In the United States, approximately $2 \%$ of all pregnant women undergo CVS or amniocentesis. The open question is, now that we have a noninvasive test, will the number of women tested increase, if not altogether skyrocket?"

Sales of the test, which can be taken 10 weeks into pregnancy, have indeed been picking up. About 1000 tests were sold in 2011 after its US release in October, at a cost of US $\$ 235$ out-of-pocket for women with private insurance and US $\$ 1900$ for the uninsured. In the first two months of 2012, about 2500 tests have been sold and Sequenom, which has set a sales target of 25000 for the year, is rapidly expanding its sales force to keep up with demand.

If the test were to one day become ubiquitous, it might be administered by

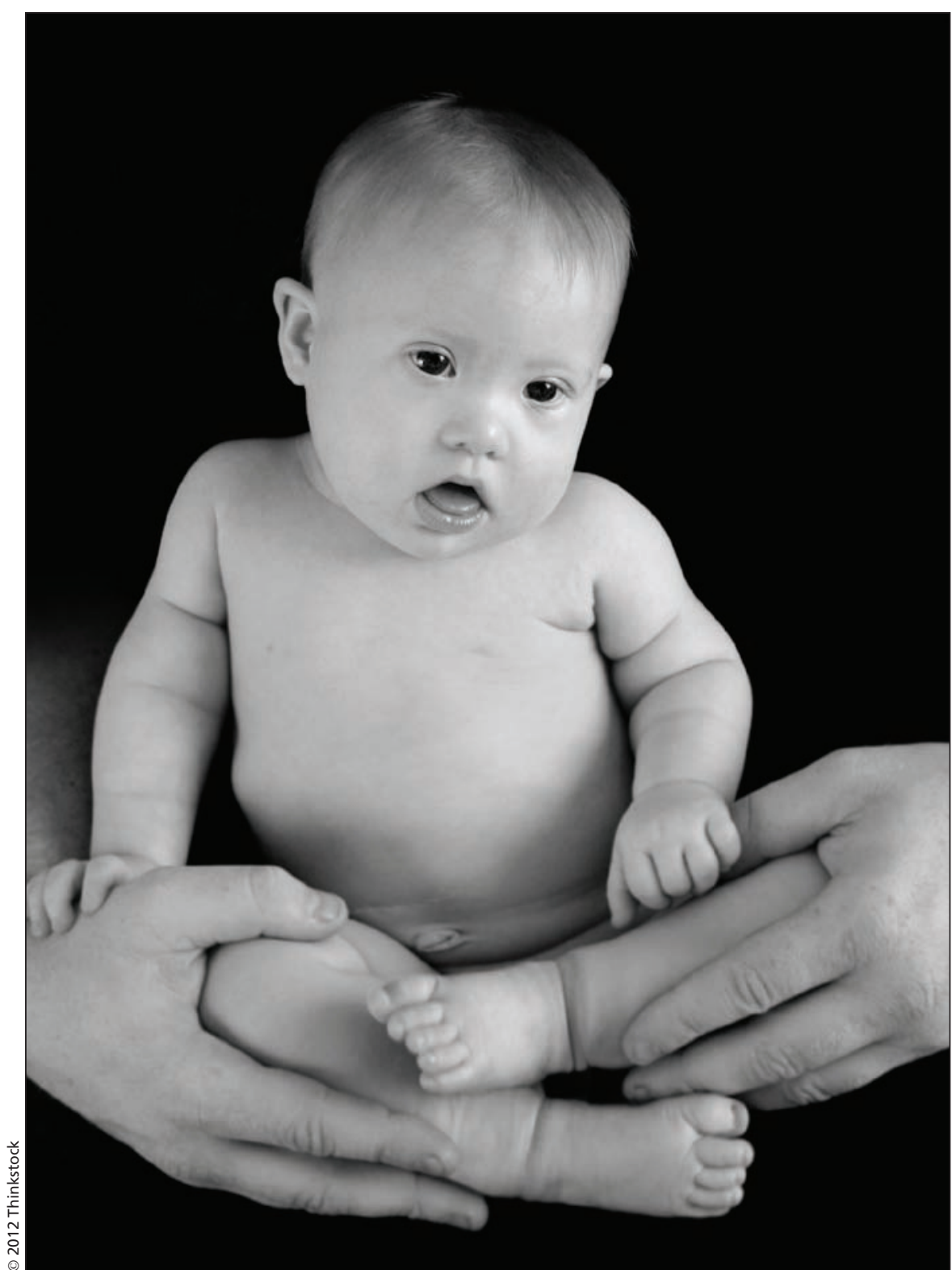

Life expectancies and health outcomes - physical and mental - for people with Down syndrome have improved greatly.

default and that could be a problem, according to Dr. Edward McCabe, executive director of the Linda Crnic Institute for Down Syndrome and professor of pediatrics at the University of Colorado School of Medicine in Aurora. "We're concerned about women who don't want to know. You could have a physician say, 'By the way, we did this test and you appear to be positive.' Then the doctors will be making the decision rather than mothers," McCabe says, adding that he's worried the decision as to "whether a family wants to have the test or not will be taken out of their hands."

Also of concern to McCabe is the potential for a large number of families to be given information on Down syndrome from physicians who know little 
about the condition or the quality of life a child born with it could expect. Life expectancies and health outcomes physical and mental - for people with Down syndrome have improved greatly, says McCabe, though that information might not be reaching families.

"We believe in informed decisionmaking," says McCabe. "Using outdated information about life expectancy and outcomes is not properly informing the family."

Not only are many doctors unable to provide accurate information about people with intellectual disabilities, there appears to be inadequate interest in training new physicians to overcome this gap, Skotko has suggested (Arch Dis Child 2009;94:823-6). Studies have indicated $81 \%$ of US medical students receive no clinical training on intellectual disabilities, $58 \%$ of medical school deans claim such training isn't a priority, and only $36 \%$ of fellows and junior fellows of the American Congress of Obstetricians and Gynecologists felt well qualified to counsel an expectant mother who receives a positive prenatal test for Down syndrome, Skotko wrote. "Taken together, these studies suggest that today's and tomorrow's physicians are not adequately prepared."

Skotko also wonders what will happen to Down syndrome research if the widespread adoption of noninvasive prenatal testing leads even more women to decide to terminate pregnancies after positive results. The number of children born with the condition is already dropping considerably. Between 1989 and 2006, there would have been an estimated increase of $42 \%$ in the number of children born with Down syndrome (because of factors such as increased age of mothers) in the absence of prenatal testing (Prenat Diagn 2011;31:389-94). During that period, however, there was actually a decrease of $11 \%$ in Down syndrome births, effectively, a 53\% difference.

"If there are fewer and fewer babies born with Down syndrome, the question is: will [research] funding agencies still consider it something worth funding?" says Skotko.

And it's not as though funding is plentiful now. "Down syndrome is the least-funded genetic condition by the NIH [National Institutes of Health], bar none," says Michelle Sie Whitten, executive director of the Global Down Syndrome Foundation. "How can we attract good scientists and good doctors? There's no money in this field. They will go into autism or go into other things. It's like a nail in the coffin."'

Her foundation is not against a better genetic test, Whitten points out. But she is concerned that the lack of money dedicated to research and education will mean misinformation about the lives of people with Down syndrome will continue to spread.

"We are not opposed to early, better, safer, cheaper testing for women," says Whitten "What we are opposed to is the idea of doctors providing inaccurate information." - Roger Collier, CMAJ

CMAJ 2012. DOI:10.1503/cmaj.109-4170

Editor's note: Tenth of a multipart series on genetic testing.

Part 1: Separating hype from reality in the era of the affordable genome (www.cmaj.ca/lookup/doi/10.1503/cmaj.109-4143).

Part 2: Popping the genetics bubble

(www.cmaj.ca/lookup/doi/10.1503/cmaj.109-4142).

Part 3: Who should hold the keys to your DNA?

(www.cmaj.ca/lookup/doi/10.1503/cmaj.109-4141).

Part 4: A race-based detour to personalized medicine

(www.cmaj.ca/lookup/doi/10.1503/cmaj.109-4133).

Part 5: Race and genetics in the doctor's office

(www.cmaj.ca/lookup/doi/10.1503/cmaj.109-4134).

Part 6: Predisposed to risk but not change

(www.cmaj.ca/lookup/doi/10.1503/cmaj.109-4157).

Part 7: Unhealthy behaviours influenced by genes and environment (www.cmaj.ca/lookup/doi/10.1503/cmaj.109-4162).

Part 8: Young women with breast cancer genes face tough choices (www.cmaj.ca/lookup/doi/10.1503/cmaj.109-4168).

Part 9: The downside of genetic screening

(www.cmaj.ca/lookup/doi/10.1503/cmaj.109-4169). 